\title{
Expressing creatine kinase in transgenic tobacco - a first step towards introducing an energy buffering system in plants
}

\author{
Judith Farrés ${ }^{1, *}$, Niklas Holmberg ${ }^{2, *}$, Uwe Schlattner ${ }^{3}$, James E. Bailey ${ }^{1}$, Theo Wallimann ${ }^{3}$ \& \\ Pauli T. Kallio ${ }^{1, * *}$ \\ ${ }^{1}$ Institute of Biotechnology, ETH-Zürich, CH-8093 Zürich, Switzerland \\ ${ }^{2}$ Unilever Research, Colworth House, Sharnbrook, Bedford MK44 1LQ, UK \\ ${ }^{3}$ Institute for Cell Biology, ETH-Zürich, CH-8093 Zürich, Switzerland
}

Received 8 December 2000; revised 19 February 2001; accepted 3 May 2001

Key words: creatine, creatine kinase, energy homeostasis, tobacco, transgenic plants

\begin{abstract}
Creatine kinase a key enzyme in cellular energy homeostasis of vertebrates offers the promise of engineering plants with enhanced stress tolerance. In order to provide plants with such an energy buffering system, tobacco was transformed with a cDNA, encoding the cytosolic brain-type isoform of chicken creatine kinase (BB-CK), the expression of which was under the control of the cauliflower mosaic virus 35S (CaMV 35S) promoter. Transgenic tobacco plants were selected and suspension cultures generated. Both transgenic plants and suspension cultures were shown to stably express enzymatically active BB-CK in vitro and in vivo, and in most cases for three successive generations $\left(\mathrm{T}_{0}-\mathrm{T}_{2}\right)$. Exogenously supplied creatine was shown to enter the plant cells and resulted in only a slight reduction in root growth at concentrations up to $10 \mathrm{mM}$. Furthermore, the BB-CK expressing tobacco plants and cell suspension cultures were able to convert creatine into phosphocreatine.
\end{abstract}

\section{Introduction}

Plants employ two parallel and independent glycolytic pathways, one localized in the plastids and the other in the cytosol. The cytosolic glycolytic network supplies plants with metabolites necessary for their development and their acclimation to unfavorable environmental conditions, such as anoxia. Acclimated plants maintain higher levels of adenylates and ATP during hypoxia, as a result of accelerated rates of glycolysis, than non-acclimated plants (Plaxton, 1996). This acclimation is associated with expression of genes that encode many of the anaerobic stress proteins. A plants tolerance to environmental stress requires a period of acclimation in its natural habitat or under agricultural conditions (Ricard et al., 1991; Vartapetian \& Jackson, 1997). However not all environmental changes are gradual and abrupt. Changes such as flooding (Setter

\footnotetext{
* Both of these authors contributed equally to this work and should be recognized as first authors.

** Author for correspondence:

E-mail: kallio@biotech.biol.ethz.ch
}

et al., 1997) or transition to microgravity (Hampp et al., 1997) can become stressful in a short period of time allowing no time for plants to adapt. Therefore, it would be advantageous for plants to store energy in an easily accessible form, which can be used rapidly during transiently increased demands for ATP, until the plant is capable of adapting to the new circumstances.

A sufficient capacity and balanced regulation of 'high-energy phosphate' supply and turnover is essential for the proper function of any cell. Large amounts of energy-rich phosphagens can be found in many cells or tissues throughout the animal kingdom, but they seem to be absent in plants (Watts, 1971; Ellington $\&$ Hines, 1991). In all vertebrates and in some invertebrates this phosphagen is phosphocreatine ( $\mathrm{PCr}$ ). $\mathrm{PCr}$ and ADP are the products of the reversible transfer of a $\gamma$-phosphate group from ATP to creatine $(\mathrm{Cr})$, a reaction catalysed by creatine kinase $(\mathrm{CK})$ (see Figure 1). This enzyme is present in tissue- as well as compartment-specific isoforms, playing a key role in the energy homeostasis of many cells and tissues (Wallimann et al., 1992; Wyss \& Kaddurah-Daouk, 2000). 


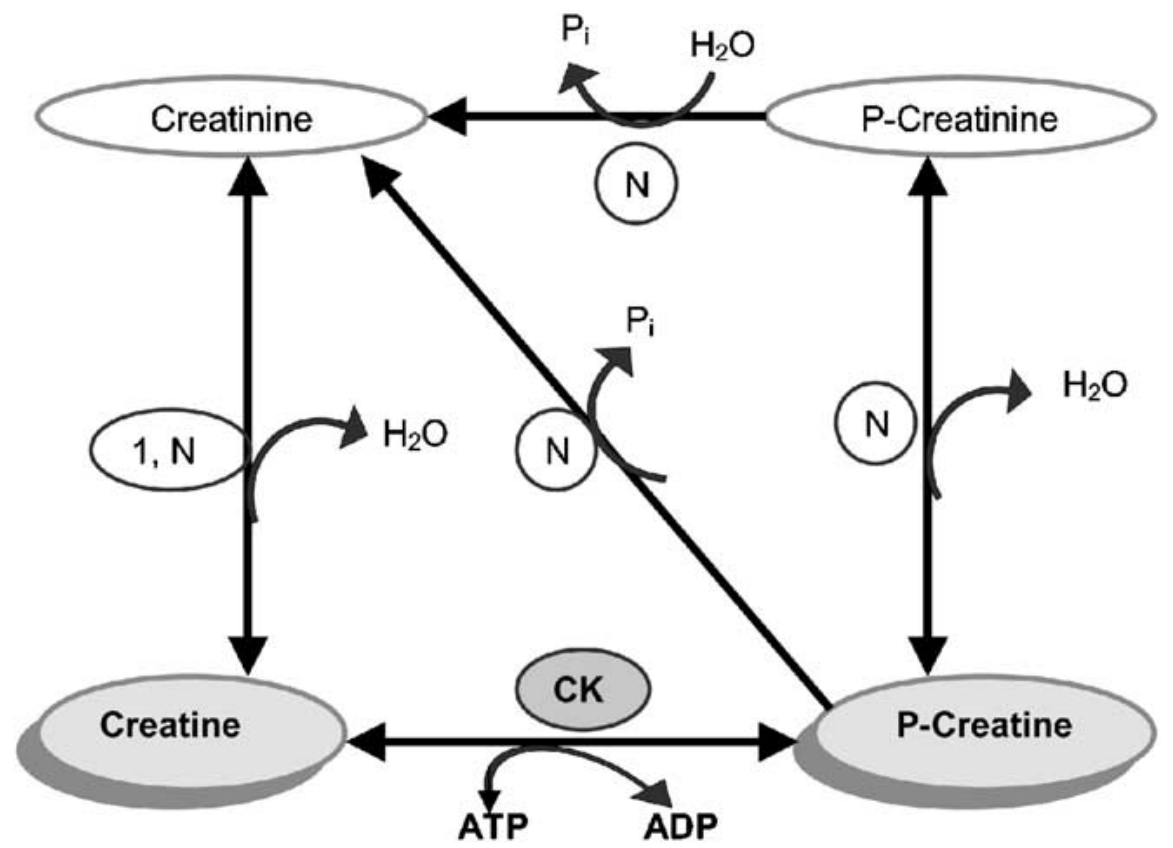

Figure 1. Schematical representation of the reactions involved in creatine metabolism, adapted from Wyss and Wallimann, 1994. CK: creatine kinase (EC 2.7.3.2); N: Nonenzymatic reaction; 1: Creatininase = creatinine amidohydrolase (EC 3.5.2.10) inducibly expressed in various bacteria.

Recently, van Voorthuyse et al. (2000) attempted the introduction of a novel $\mathrm{P}_{\mathrm{i}}$ pool into plant cells in order to provide cells with storage energy in the form of phosphate. Potato plants were engineered to express polyphosphate kinase, which catalyses the synthesis of long chain polyphosphate. Polyphosphate kinase was shown to catalyze the synthesis of poly- $\mathrm{P}_{\mathrm{i}}$ in planta. However, the reverse reaction in which $\mathrm{P}_{\mathrm{i}}$ is released could not be detected.

Modern biotechnology offers unlimited opportunities to transfer useful traits from one organism to another. Introduction and expression of cytoplasmic CK into cells that normally do not express the enzyme has been reported, in mouse liver cells, Escherichia coli, and Saccharomyces cerevisiae (Koretsky \& Traxler, 1989; Brindle et al., 1990; Koretsky et al., 1990). All these studies demonstrated expression of enzymatically active CK. Furthermore, in mouse liver and E. coli, the in vivo generation of $\mathrm{PCr}$ from $\mathrm{Cr}$ could also be verified. Transgenic mouse-liver expressing $\mathrm{CK}$ also showed increased protection against hypoxia and ischemia (Miller et al., 1993). Thus, it would be of great agricultural value if the CK energy buffering system could be introduced in crops in order to overcome abrupt deficits in the energy supply. Several components are required in order to introduce the CK energy buffering system into plants. Firstly, a fully active CK has to be expressed and secondly, either a creatine uptake system or a biosynthetic pathway for the production of creatine needs to be present. The presence of creatine in plants has, to our knowledge, never previously been reported. Nevertheless, there are reports studying the effects of creatine in the unicellular alga, Gonyaulax polyedra, which demonstrated a shortening of the circadian period (Roenneberg et al., 1988; Roenneberg \& Taylor, 1994). This result may indirectly indicate that $\mathrm{Cr}$ can enter into plant cells, although no definite proof to support this suggestion has been provided yet. The precursor of creatine synthesis in vertebrates is Arginine, an amino acid that is also synthesized in plants. Arginine is converted into $\mathrm{Cr}$ via two enzymatic steps catalyzed by glycine amidotransferase and guanidinoacetate methyl-transferase (for a review see Wyss \& Kaddurah-Daouk, 2000).

Initially to establish a CK energy circuit into plants we transformed tobacco plants with the coding sequence of the chicken cytosolic brain-type creatine kinase (BB-CK) gene. The expression of BB-CK was under the control of the constitutive CaMV 35S promoter, which is known to be active in most plant-tissue types. This CK isoform is active as a dimer with a molecular mass of $43 \mathrm{kDa}$ per subunit (Wirz et al., 1990; 
Eder et al., 1999). The main goals of this study are to investigate: (i) if CK can be functionally expressed in tobacco plants, (ii) if creatine can enter into tobacco cells when supplied exogenously, (iii) if $\mathrm{Cr}$ can be converted into $\mathrm{PCr}$ in $\mathrm{CK}$-expressing plants, and (iv) if the expression of $\mathrm{CK}$ in tobacco has any phenotypical consequences.

\section{Materials and methods}

\section{$B B-C K$ cDNA cloning}

The cDNA encoding mature chicken BB-CK was PCR amplified from a template plasmid pAAH5/BbCK (Furter \& Wallimann, not published) using Pwo DNA polymerase and oligonucleotide primers BbCK1 and BbCK2, (Microsynth, Balgach, Switzerland). Primer BbCK1 ( $5^{\prime}$-at tct aga ATG CCC TTC TCA AAC AGC CAC-3') hybridizes to the $5^{\prime}$-end and BbCK2 (5'-ta taa get tca TTA TTT CTG AGC TGG CAT GAG G-3') hybridizes to the $3^{\prime}$-end of the cDNA of BB-CK. These primers introduce new restriction enzyme sites $\mathrm{XbaI}$ (BbCK1) and HindIII (BbCK2) into BB-CK cDNA and are underlined. The coding sequence of BB-CK cDNA is writen in capital letters. The PCR amplified cDNA was double digested with $\mathrm{XbaI}$ and HindIII and inserted into plasmid pSL1180 (Amersham Pharmacia Biotech) generating $\mathrm{pBbCK}$. The PCR amplification was carried out in a thermal cycler of Perkin Elmer (Gene Amp 9600 PCR system) using standard PCR techniques (Saiki et al., 1988). The gene sequence was verified from both strands by DNA sequencing (Sanger et al., 1977) and using an automated DNA sequencer of LI-COR 4000 L (LI-COR, Lincoln, NE; Andersson et al., 2000). The XbaI, HindIII fragment was subcloned into prokaryotic expression vector pTrc99a (Amersham Pharmacia Biotech), yielding pTBbCK. E. coli DH5a (Bethesda Research Laboratories) was used as a host in all cloning and sub-cloning procedures. A palindromic oligonucleotide $\left(5^{\prime}\right.$-AGC TCT CTA GAG-3') was hybridized with itself to create an XbaI (underlined) holding linker with HindIII sites in either end. Vector pTBbCK was digested with HindIII, dephosphorylated by alkaline phosphatase, and the $\mathrm{XbaI}$ holding linker was inserted to give $\mathrm{pXB}$ bCK. In order to remove the uidA gene, the binary plant expression vector pBI121 (Clontech, Palo Alto, USA) was digested with SmaI and $S a c$ I, treated with Klenow enzyme and self-ligated to generate pBI121 (without uidA). Plasmid pXBbCK was digested with
$X b a I$ to release the BB-CK cDNA, which was concomitantly inserted into the XbaI site of pBI121 (without uidA), downstream of the CaMV 35S promoter and upstream of the nopaline synthase (NOS) terminator, yielding vector $\mathrm{pPBbCK}$.

\section{Tobacco transformation}

pPBbCK and pBI121 were transformed into Agrobacterium tumefaciens LBA4404 using electroporation as described by Shen and Forde (1989). Agrobacteriumtransformation of Nicotiana tabacum SR1 was carried out as described previously (Rogers et al., 1986). Kanamycin resistant seedlings were obtained and screened by PCR to identify potential transformants for chromosomal integration of the cDNA encoding BB-CK by using the primer pair BbCK1/BbCK2 (Edwards et al., 1991). PCR positive transformants were also analyzed for BB-CK expression by western immunoblots as described below. pBI121 positive seedlings were identified by histochemical GUS staining of non-fixed plant leaves (Gallagher, 1992).

\section{Propagation of tobacco plants}

BB-CK expressing seedlings were transferred to soil and grown in the greenhouse (day: $16 \mathrm{~h}, 25^{\circ} \mathrm{C}$; night: $8 \mathrm{~h}, 18^{\circ} \mathrm{C}$ ) until seeds were collected from dried plants. The Mendelian segregation pattern was deduced by germinating $\mathrm{T}_{1}$ and $\mathrm{T}_{2}$ seeds on MS-medium (Murashige \& Skoog, 1962), supplemented with kanamycin $(100 \mathrm{mg} / \mathrm{l})$, and counting the number of surviving shoots. Kanamycin resistant plantlets from the $T_{1}$ generation and plantlets originating from previously identified homozygous lines in the case of the $\mathrm{T}_{2}$ generation, were selected for growth experiments in creatine containing media. Plantlets at the four leaf stage were transferred to sterile containers with MS-medium, 3\% (w/v) sucrose, $0.3 \%(\mathrm{w} / \mathrm{v})$ Gelrite $^{\circledR}$ (Duchefa, Haarlem, the Netherlands), and supplemented with varying concentrations of creatine (0 mM, $5 \mathrm{mM}, 10 \mathrm{mM}, 15 \mathrm{mM}, 30 \mathrm{mM}$ and $60 \mathrm{mM}$ ). The development of the plants was visually assessed.

\section{Establishment of tobacco suspension cultures}

Callus formation was induced by placing young leafdiscs of $\mathrm{T}_{1}$ transgenic lines on LS-medium (Linsmaier \& Skoog, 1965) supplemented with $3 \%$ (w/v) sucrose, $0.5 \%$ (w/v) agargel (Sigma), $0.2 \mathrm{mg} / \mathrm{l}$ 2,4dichlorophenoxyacetic acid (Duchefa), $0.19 \mathrm{mg} / \mathrm{l} \alpha-$ naphtalene acetic acid (Duchefa), and $50 \mathrm{mg} / \mathrm{l}$ 


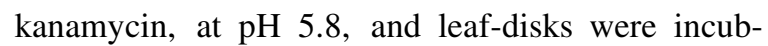
ated in the dark at $25^{\circ} \mathrm{C}$. Developed callus tissue was transferred to $190 \mathrm{ml}$ sterile plastic containers with $20 \mathrm{ml}$ of liquid media (LS-medium with the above described supplements but without agar) and incubated on a rotary shaker LS-W (Kühner, Birsfelden, Switzerland), at $110 \mathrm{rpm} 25^{\circ} \mathrm{C}$ in the dark. Cells were routinely sub-cultured (filtered through a sieve and resuspended in fresh liquid medium) every 7-10 days. For growth measurements cultures were grown in $250 \mathrm{ml}$ cultivation flasks with $50 \mathrm{ml}$ of liquid medium.

\section{SDS-PAGE and western immunoblot analysis}

Leaf tissue from young tobacco plants or pelleted cell suspensions were macerated on ice in 2 volume of homogenization buffer $(100 \mathrm{mM}$ Tris- $\mathrm{HCl}, \mathrm{pH}$ 7.0, $100 \mathrm{mM} \mathrm{NaCl}, 20 \mathrm{mM}$ EDTA and $1 \mathrm{mM}$ PMSF) using a micropestle and cell debris were removed by centrifugation. Total soluble protein concentration in the extracts was determined by Bradford (1976) method, using reagents obtained from BioRad and bovine serum albumin as a standard. Soluble protein fractions were separated in a $12 \%$ SDS-PAGE gel electrophoresis (Laemmli, 1970). The separated proteins were transferred electrophoretically onto an Immobilon-P nylon membrane (Millipore) using a TE Transphor Electrophoresis Unit (Hoefer) according to the manufacturer's protocol. Rabbit anti-B-CK antibodies (obtained from Dr. Wallimann, ETH-Zürich) were used as primary antibodies to detect BB-CK. Goat anti-rabbit IgG horseradish peroxidase conjugate (BioRad, Hercules, USA), was used as secondary antibody. Chemiluminiscent detection was performed using ECL western blotting detection reagents (Amersham Pharmacia Biotech) according to the supplier's instructions. Densitometry scanning was used to compare the intensities of the BB-CK bands, arising from the transgenic plants, to the intensity of the band of pure chicken BB-CK (heterologously expressed in E. coli and obtained from Dr. Wallimann), using a PhosphoImager SF and a software package Imagequant (Molecular Dynamics) or SigmaScan (Jandel Scientific).

\section{Determination of CK activity}

Leaf tissue or cell suspensions were ground to a fine powder with a micropestle under liquid nitrogen and mixed with 2 volume of assay buffer $(10 \mathrm{mM}$ sodium phosphate, $\mathrm{pH} 7.0,100 \mathrm{mM} \mathrm{NaCl}, 0.2 \mathrm{mM}$ EDTA, $1 \mathrm{mM} \beta$-mercaptoethanol, and $1 \mathrm{mM}$ PMSF).
The homogenates were centrifuged and supernatants decanted. CK activity was determined by directly measuring the transphosphorylation rate of $\mathrm{PCr}$ in the reverse $\mathrm{CK}$ reaction $\left(\mathrm{MgADP}^{-}+\mathrm{PCr}^{2-}+\mathrm{H}^{+} \rightarrow\right.$ $\mathrm{MgATP}^{2-}+\mathrm{Cr}$ ) using the pH-stat method (Watts, 1973). The reaction buffer contained $7.5 \mathrm{mM} \mathrm{KCl}$, $10 \mathrm{mM} \mathrm{MgCl}_{2}, 0.1 \mathrm{mM}$ EGTA, and $1 \mathrm{mM} \beta$-mercaptoethanol. $\mathrm{PCr}$ and ADP were added to a final concentration of $10 \mathrm{mM}$ and $4 \mathrm{mM}$, respectively, and the reaction was performed at $\mathrm{pH} 7.00$. Expression rates (\% of total soluble protein) were calculated assuming a specific activity of BB-CK of $240 \mathrm{U} / \mathrm{mg}$ as reported by Eder et al. (1999).

\section{Detection of $\mathrm{Cr}, \mathrm{PCr}$ and $\mathrm{Crn}$}

Protein-free extracts were prepared by quick-freezing of harvested plant material in liquid nitrogen. The frozen leaves or cell suspension were ground to powder and incubated in 3 volume of $6 \%(\mathrm{v} / \mathrm{v})$ perchloric acid on ice for $30 \mathrm{~min}$. Extracts were centrifuged, supernatants were decanted and neutralized to pH 7 with $5 \mathrm{M} \mathrm{KHCO}_{3}$, incubated on ice for $30 \mathrm{~min}$ to allow $\mathrm{KClO}_{2}$ precipitation, and centrifuged again. $\mathrm{Cr}$, $\mathrm{PCr}$ and Crn were separated by reverse-phase HPLC in a Sephasil Peptide C18, st. 4.6/250 column (Amersham Pharmacia Biotech). Samples were loaded in eluent A (50 mM KH $2 \mathrm{PO}_{4}, 5 \mathrm{mM}$ TBAHS, pH 6) and a linear gradient of eluent B (eluent A with $40 \%$ $(\mathrm{v} / \mathrm{v})$ methanol) was used for elution at a flow rate of $1 \mathrm{ml} / \mathrm{min}$. Metabolites were detected by measuring the absorbance at 254 and $214 \mathrm{~nm}$. The assignment of peaks was made by running external and internal standards ( $\mathrm{Cr}, \mathrm{PCr}$ and $\mathrm{Crn})$.

\section{Quantification of $\mathrm{Cr}$ and $\mathrm{PCr}$}

Purified HPLC fractions were assayed for $\mathrm{Cr}$ or $\mathrm{PCr}$ content using a photometric coupled enzyme assay (Bernt et al., 1974). The $\mathrm{Cr}$ concentration was determined by using the forward $\mathrm{CK}$ reaction coupling the production of ADP to NAD by lactate dehydrogenase $(8 \mathrm{U} / \mathrm{ml})$ and pyruvate kinase $(1.6 \mathrm{U} / \mathrm{ml})$. Composition of the reaction mixture was as follows: $4 \mathrm{mM}$ ATP, $4.5 \mathrm{mM}$ magnesium acetate, $0.9 \mathrm{mM}$ phosphoenolpyruvate, and $0.45 \mathrm{mM}$ NADH in $0.1 \mathrm{M}$ triethanolamine buffer, $\mathrm{pH}$ 8. The decrease in absorbance at $340 \mathrm{~nm}$ was monitored to determine the $\mathrm{Cr}$ concentration. To determine the $\mathrm{PCr}$ concentration the production of ATP (reverse reaction) was coupled to NADH production using hexokinase $(3 \mathrm{U} / \mathrm{ml})$ and glucose-6phosphate dehydrogenase $(1.5 \mathrm{U} / \mathrm{ml})$ in a $0.1 \mathrm{M}$ trieth- 
Table 1. Enzymatic CK activity and Bb-CK content in primary BB-CK-expressing transgenic plants $\left(\mathrm{T}_{0}\right)$

\begin{tabular}{|c|c|c|c|}
\hline \multirow[t]{2}{*}{ Plant } & \multicolumn{2}{|c|}{ Enzymatic CK activity } & \multirow{2}{*}{$\begin{array}{l}\text { Western blot } \\
\text { (BB-CK \% relative to total } \\
\text { soluble protein content) }\end{array}$} \\
\hline & (U/mg protein) & $\begin{array}{l}\text { (BB-CK \% relative to total } \\
\text { soluble protein content) }\end{array}$ & \\
\hline Bi:1 & 0 & 0 & 0 \\
\hline BB:2 & 0.86 & 0.35 & 2.2 \\
\hline BB:12 & 0.15 & 0.06 & ND \\
\hline PB:5 & 0.10 & 0.04 & 0.61 \\
\hline PB:8 & 0 & 0 & 0.14 \\
\hline PB:10 & 0.14 & 0.05 & $\mathrm{ND}$ \\
\hline PB:18 & 0.22 & 0.09 & 0.18 \\
\hline PB:19 & 0.05 & 0.02 & 0.51 \\
\hline
\end{tabular}

Bi: plants are transformed with the control vector $\mathrm{pBI} 121$; $\mathrm{BB} \& \mathrm{~PB}$ : plants are transformed with the pPBbCK, carrying the cDNA of BB-CK; ND: not determined; BB-CK: percentage of total soluble protein for the enzymatic activity measurements was calculated assuming a specific activity for BB-CK of $240 \mathrm{U} / \mathrm{mg}$ soluble protein (Eder et al., 1999).

anolamine buffer ( $\mathrm{pH} 7.0)$ supplemented with $2 \mathrm{mM}$ ADP, $5 \mathrm{mM} \mathrm{MgCl}, 40 \mathrm{mM}$ D-glucose, $250 \mathrm{ng} / \mathrm{ml}$ $\mathrm{CK}, 1 \mathrm{mM}$ NADP, and $1 \mathrm{mM} \beta$-mercaptoethanol. The increase in absorbance at $340 \mathrm{~nm}$ was monitored to determine the $\mathrm{PCr}$ concentration.

\section{Results}

\section{$B B-C K$ transformation}

The cDNA encoding chicken BB-CK was amplified by PCR to introduce new restriction enzyme sites HindIII and $\mathrm{XbaI}$, which facilitate further subcloning steps. No errors were introduced by PCR into the coding sequence of BB-CK which was verified by DNA sequencing.

BB-CK expression vector pPBbCK and control vector pBI121 were transformed into tobacco via Agrobacterium-mediated gene transfer and kanamycin resistant seedlings were selected. Thirty kanamycin resistant seedlings were analyzed by PCR for presence of the BB-CK transgene. In total, 24 seedlings had integrated the BB-CK cDNA in the genome resulting in a transformation rate of approximately $80 \%$ (data not shown). pBI121 positive seedlings were identified by histochemical GUS staining (data not shown).

\section{Transgenic tobacco plants and suspension cultures express active $B B-C K$}

Total soluble protein extracts of primary transgenic $\left(\mathrm{T}_{0}\right)$ and control lines were subjected to protein im- munoblot analysis. A protein corresponding to the theoretical molecular mass of BB-CK $(43 \mathrm{kDa})$ was detected in several of the transgenic lines, but not in the control lines (data not shown). The amount of BB-CK in the different lines was estimated by densitometry (Table 1). In particular, the highest expressing line BB:2 contained approximately $2 \%$ of BB-CK in relation to the total soluble protein content. This line also showed the highest enzymatic CK activity, 0.86 $\mathrm{U} / \mathrm{mg}$ of soluble protein, which was measured using the $\mathrm{pH}$-stat method. Assuming a specific activity for BB-CK of $240 \mathrm{U} / \mathrm{mg}$ of soluble protein (Eder et al., 1999), line BB:2 has a BB-CK content of $0.35 \%$ relative to the total soluble protein content. In all cases, the calculated BB-CK percentage with respect to the total protein content based on activity measurements is lower than the percentage calculated from the western blots (Table 1).

Three of the highest BB-CK-expressing transgenic lines, BB:2, PB:5 and PB:10, together with Bi:1 (control line) were selected for further analysis in the subsequent $T_{1}$ and $T_{2}$ generations. Selective germination assays on kanamycin supplemented medium were conducted to identify those plants that had retained the kanamycin resistance trait during the Mendelian segregation. Approximately $75 \%$ of the germinated $\mathrm{T}_{1}$ seeds developed proliferating seedlings, which is indicative of a Mendelian segregation ratio of 3:1 (data not shown). Kanamycin resistant seedlings were transferred to soil and grown until $\mathrm{T}_{2}$ seeds were collected. $\mathrm{T}_{1}$ plants giving $100 \%$ kanamycin resistant seeds were concluded to be homozygous.

Individual plants of the BB:2, PB:5, PB:10, and $\mathrm{Bi}: 1$ lines in the $\mathrm{T}_{1}$ generation were subjected to im- 

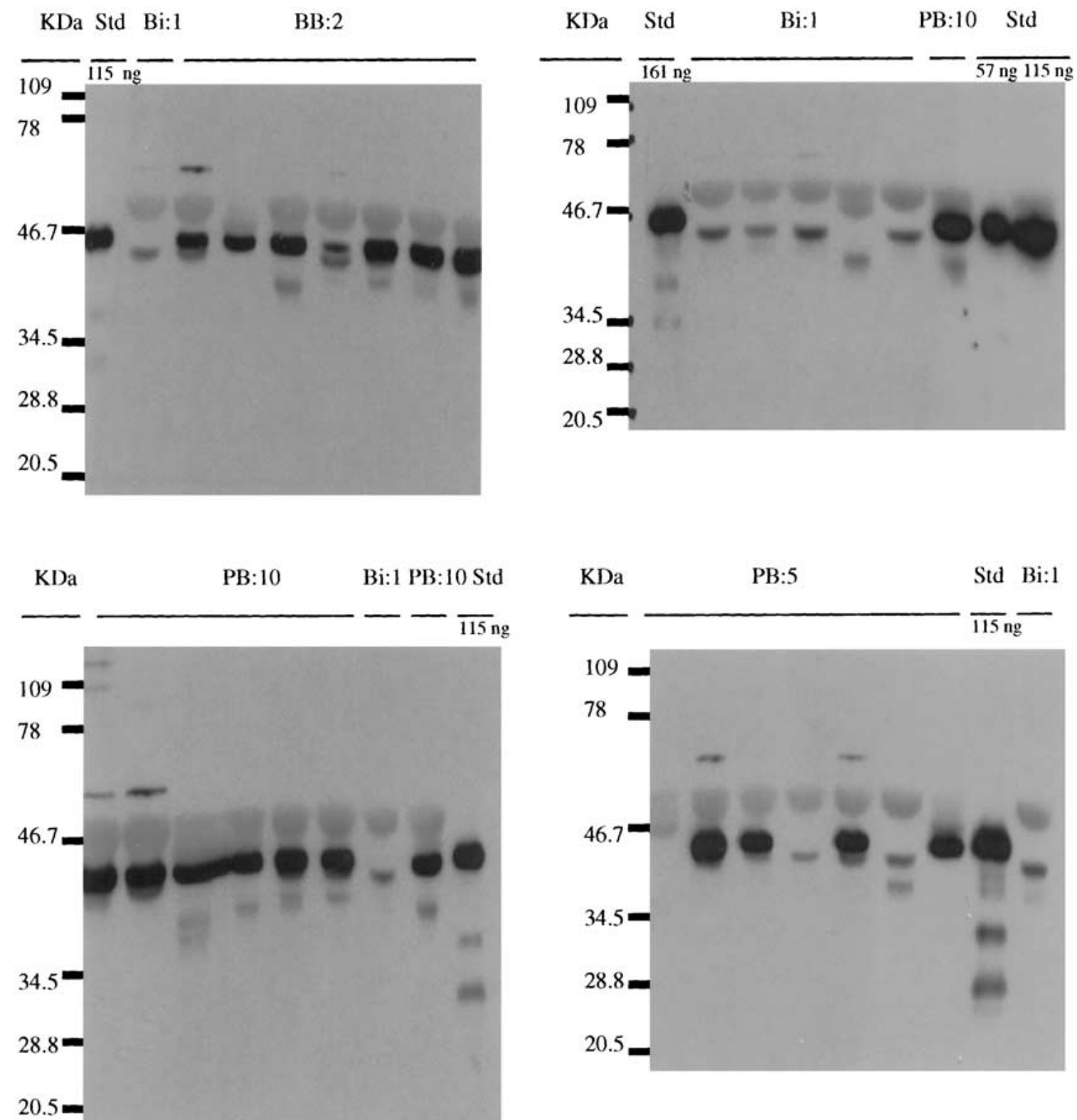

Figure 2. Western blot from leaves of $\mathrm{T}_{1}$ plants. (Bi) plants transformed with control vector $\mathrm{pBi121}$. (BB and $\mathrm{PB}$ ) plants transformed with $\mathrm{pPBbCK}$, carrying the BB-CK transgene. As a positive standard, pure rDNA produced chicken BB-CK was used.

munoblot analysis (Figure 2). On average the BB-CK expression of lines BB:2, PB:5 and PB:10 was 1.0, 0.7 and $0.8 \%$, respectively, with respect to the total soluble protein content (Table 2). BB-CK expression in roots was also assayed by immunoblot analysis for line BB:2 (Figure 3). Enzymatic CK activity measurements for those lines in the $\mathrm{T}_{1}$ and $\mathrm{T}_{2}$ generations are also summarized in Table 2. Line BB:2 showed again the highest $\mathrm{CK}$ activity both in $\mathrm{T}_{1}(0.146 \mathrm{U} / \mathrm{mg}$ sol- uble protein) and in $\mathrm{T}_{2}(0.191 \mathrm{U} / \mathrm{mg}$ soluble protein $)$ generations, but lower than in $\mathrm{T}_{0}$.

Tobacco-suspension cultures derived from the highest BB-CK-expressing $\mathrm{T}_{1}$ transgenic line, BB:2, were generated as described in materials and methods. They showed BB-CK expression as judged by protein immunoblot analysis (Figure 4) and measuring enzymatic activity of CK (20.4 U/ng of dry weight). 
Table 2. Enzymatic CK activity and BB-CK content of transgenic and control plants in the $\mathrm{T}_{1}$ and $\mathrm{T}_{2}$ generations

\begin{tabular}{|c|c|c|c|c|c|}
\hline \multirow[t]{4}{*}{ Plant lines } & \multicolumn{4}{|c|}{ CK activity } & \multirow{4}{*}{$\begin{array}{l}\text { Western blot } \\
\text { (BB-CK \% relative to total } \\
\text { soluble protein content) } \\
\mathrm{T}_{1}\end{array}$} \\
\hline & \multirow{2}{*}{\multicolumn{2}{|c|}{ (U/mg protein) }} & \multirow{2}{*}{\multicolumn{2}{|c|}{$\begin{array}{l}\text { (BB-CK \% relative to total } \\
\text { c } \quad \text { soluble protein content) }\end{array}$}} & \\
\hline & & & & & \\
\hline & $\mathrm{T}_{1}$ & $\mathrm{~T}_{2}$ & $\mathrm{~T}_{1}$ & $\mathrm{~T}_{2}$ & \\
\hline Bi:1 & $0.012 \pm 0.007$ & 0.034 & 0.01 & 0.01 & 0 \\
\hline BB: 2 & $0.146 \pm 0.096$ & 0.191 & 0.06 & 0.08 & $1.0 \pm 0.4$ \\
\hline PB:5 & $0.115 \pm 0.0004$ & 0.168 & 0.05 & 0.07 & $0.7 \pm 0.2$ \\
\hline PB: 10 & $0.146 \pm 0.085$ & 0.049 & 0.06 & 0.02 & $0.8 \pm 0.3$ \\
\hline
\end{tabular}

$\mathrm{Bi}$ : plants are transformed with the control vector $\mathrm{pBI} 121$; $\mathrm{BB}$ and $\mathrm{PB}$ : plants are transformed with the pPBbCK, carrying the BB-CK transgene. Two plants per line were used to assay CK activity, while 4-10 plants per line were used for estimation of BB-CK abundance from western blots, mean values are given $( \pm)$ standard deviation; BB-CK: percentage of total soluble protein for the enzymatic activity measurements was calculated assuming a specific activity for BB-CK of $240 \mathrm{U} / \mathrm{mg}$ soluble protein (Eder et al., 1999).

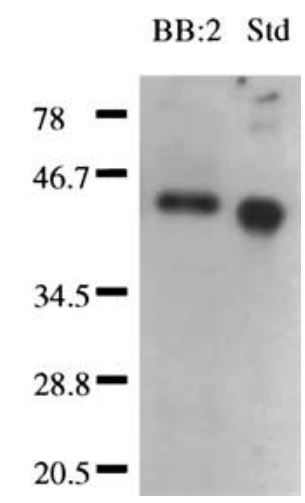

Figure 3. Western blot from roots of $\mathrm{T}_{1}$ plants. (BB) plant transformed with $\mathrm{pPBbCK}$, carrying the $\mathrm{BB}-\mathrm{CK}$ transgene. As a positive standard, $115 \mathrm{ng}$ of pure rDNA produced chicken BB-CK was used.

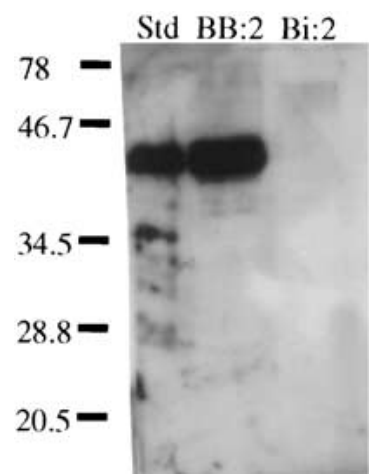

Figure 4. Western blot from tobacco suspension cultures. (Bi) suspension cultures derived from plants transformed with control vector pBi121. (BB) suspension cultures derived from plants transformed with $\mathrm{pPBbCK}$, carrying the $\mathrm{BB}-\mathrm{CK}$ transgene. As a positive standard, pure rDNA produced chicken BB-CK was used.

\section{Growth in creatine}

BB-CK-expressing and control plants (transformed with the parental vector pBI121 only) were grown on media containing different $\mathrm{Cr}$ concentrations ( 0 , $5,10,15,30$ and $60 \mathrm{mM})$. At concentrations higher than $30 \mathrm{mM} \mathrm{Cr}$ the plant growth was strongly inhibited. Plants developed almost normally in $10 \mathrm{mM}$ $\mathrm{Cr}$, with the exception that root growth was slightly inhibited. In contrast, when plants were grown in $10 \mathrm{mM}$ creatinine $(\mathrm{Crn})$, the product of $\mathrm{Cr}$ breakdown, plant growth was significantly inhibited. In all these assays no differences were observed between BB-CK-expressing and control plants, with or without creatine or creatinine supplementation (data not shown).

Tobacco-suspension cultures grown in $\mathrm{Cr}$ containing media showed growth inhibition when either $5 \mathrm{mM}$ or $10 \mathrm{mM} \mathrm{Cr}$ was added at the beginning of growth, but showed almost no inhibition when $5 \mathrm{mM} \mathrm{Cr}$ was added after 4 days of growth (Figure 5). This behavior was observed for both transgenic and control tobacco-suspension cultures, with or without creatine supplementation (data not shown for the control line).

$\mathrm{Cr}$ and $\mathrm{Crn}$ were detected in protein-free extracts of plants and suspension cultures grown in creatine. Only in BB-CK-expressing plants and suspension cultures the presence of $\mathrm{PCr}$ was also detected. $\mathrm{Cr}$ and $\mathrm{PCr}$ were purified from the protein-free extracts by HPLC and quantified by a photometric coupled enzymatic assay. The amount of $\mathrm{PCr}$ detected in $\mathrm{T}_{1}$ plants grown in the presence of $10 \mathrm{mM}$ creatine in the media ranged from 0.59 to $0.24 \mu \mathrm{mol} / \mathrm{g}$ fresh weight. But if plants were transferred to a creatine-free media for 3 days, the PCr content was substantially reduced, $0.08-0.04 \mu \mathrm{mol} / \mathrm{g}$ fresh weight (Table 3 ). The amount 


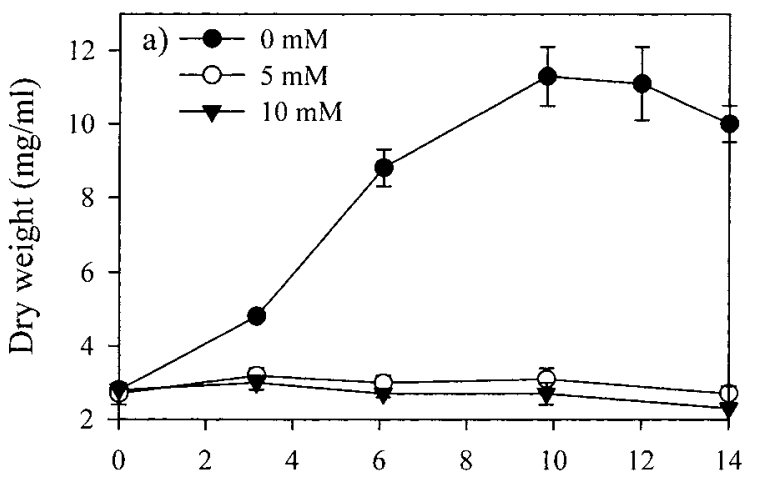

Time (days)

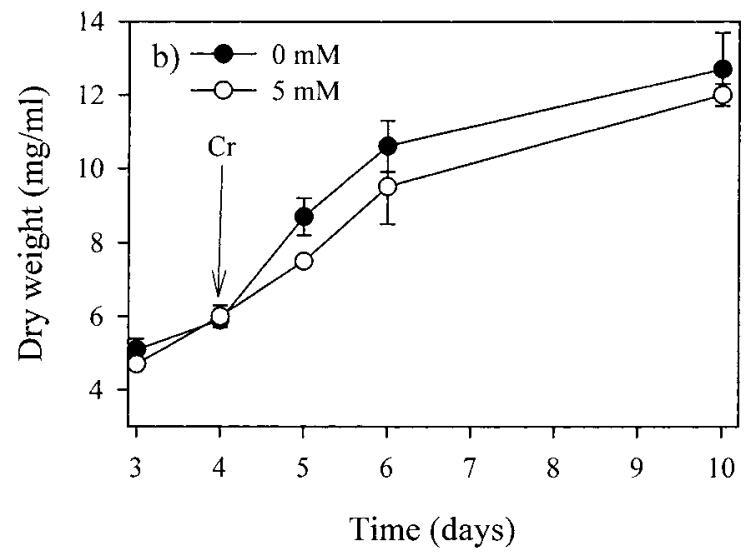

Figure 5. Effect of creatine on the growth of tobacco suspension cultures expressing BB-CK (BB:2). (a) Growth on two different concentration of $\mathrm{Cr}$ (added at time point zero) and a control without the addition of $\mathrm{Cr}$. (b) Growth on $5 \mathrm{mM} \mathrm{Cr}$, added after 4 days, and a control without the addition of Cr. All cultures were done in triplicates; error bars correspond to standard deviation.

Table 3. PCr content in $\mathrm{T}_{1}$ plants

\begin{tabular}{lc}
\hline Plant & $\begin{array}{c}\mathrm{PCr} \\
(\mu \mathrm{mol} / \mathrm{g} \\
\text { fresh weight })\end{array}$ \\
\hline PB:10.6* & 0.59 \\
PB:10.5* & 0.58 \\
BB: $2.3^{*}$ & 0.24 \\
PB:10.1** & 0.04 \\
BB: $2.3^{* *}$ & 0.08 \\
\hline
\end{tabular}

$\mathrm{BB}$ and $\mathrm{PB}$ : plants are transformed with the pPBbCK, carrying BB-CK transgene; *Plants are grown for 12 days in $10 \mathrm{mM} \mathrm{Cr}$; ${ }^{* *}$ Plants are grown for 9 days in $10 \mathrm{mM} \mathrm{Cr}$ followed by 3 days without Cr.
Table 4. $\mathrm{Cr}$ and $\mathrm{PCr}$ content in homozygous $\mathrm{T}_{2}$ plants. Plants were grown for 6 days in $5 \mathrm{mM} \mathrm{Cr}$

\begin{tabular}{lll}
\hline Plant & \multicolumn{2}{l}{$\begin{array}{l}\text { Cr } \\
(\mu \mathrm{mol} / \mathrm{g} \text { fresh weight })\end{array}$} \\
\hline Bi:1.3 & 4.3 & 0.04 \\
BB:2.4 & 4.0 & 0.22 \\
PB:5.2 & 6.4 & 0.38 \\
\hline
\end{tabular}

$\mathrm{Bi}$ : plants are transformed with the control vector pBI121; $\mathrm{BB}$ and $\mathrm{PB}$ : plants are transformed with the $\mathrm{pPBbCK}$, carrying BB-CK transgene.

of $\mathrm{Cr}$ detected in control and $\mathrm{BB}-\mathrm{CK}$ transgenic lines, analyzed at $\mathrm{T}_{2}$ generation, was approximately the same. The control line, Bi:1.3, contained $4.3 \mu \mathrm{mol}$ of $\mathrm{Cr} / \mathrm{g}$ fresh weight while BB-CK-expressing plants, BB:2.4 and PB:5.2, contained 4.0 and $6.4 \mu \mathrm{mol}$ of $\mathrm{Cr} / \mathrm{g}$ fresh weight, respectively. In contrast, $\mathrm{PCr}$ was detected in BB-CK-expressing plants, but not in the control lines, in a concentration, which is approximately 17 times lower than that of $\mathrm{Cr}$ (Table 4). $\mathrm{Cr}$ and $\mathrm{PCr}$ were also detected in protein-free extracts of BB$\mathrm{CK}$-expressing tobacco suspension cultures grown in media containing $5 \mathrm{mM} \mathrm{Cr}$ in the media (Table 5). The amount of $\mathrm{PCr}$ did not vary with increasing time of incubation and the calculated concentration ratio of $\mathrm{Cr}$ to $\mathrm{PCr}$ remained relatively constant being $50: 1$.

Table 5. $\mathrm{Cr}$ and $\mathrm{PCr}$ content in $\mathrm{BB}-\mathrm{CK}$-expressing tobacco suspension cultures, line BB:2, grown in $5 \mathrm{mM}$ $\mathrm{Cr}$

\begin{tabular}{lll}
\hline $\begin{array}{l}\text { Time of incubation } \\
\text { (days) }\end{array}$ & $\begin{array}{l}\mathrm{Cr} \\
\text { (nmols/mg dry weight) }\end{array}$ & $\mathrm{PCr}$ \\
\hline 1 & 63 & 0.7 \\
2 & 28 & 0.6 \\
6 & 36 & 0.6 \\
\hline
\end{tabular}

\section{Discussion}

In this study we engineered tobacco lines to express enzymatically active BB-CK in vitro and in vivo. Moreover, the BB-CK expression was shown to be stable in three successive generations $\left(\mathrm{T}_{0}-\mathrm{T}_{2}\right)$, except for line BB:2 were the expression was reduced in $\mathrm{T}_{1}$ and $T_{2}$ generations. Suspension cultures were also able to show stable expression.

A variation in the expression rate of BB-CK among the different transgenic lines was observed. The sites 
of integration in the genome, as well as the number of insertions of the transgene, are known to influence the expression efficiency (Gallie, 1998; Kooter et al., 1999). Three of the highest expressing lines $\mathrm{BB}: 2, \mathrm{~PB}: 10$ and PB:5 demonstrate a 3:1 segregation ratio, which is indicative of transgene (one or more copies) insertion into a single locus. We found approximately 10 -fold discrepancy between the expression levels of BB-CK, which were estimated from activity measurements and those which were estimated from western blots. Although, densitometry determination of protein amounts is inherently imprecise, it is plausible to assume that the discrepancies between those values and the values obtained from CK activity measurements may be due to a partial inhibition of the enzyme activity in crude plant extracts. This may also explain why only lines with high BB-CK expression exhibited enzyme activity. In fact, it has been shown that plant growth regulators can affect the activity of CK in vitro (Celik \& Kara, 1997). The amount of BB-CK produced in lines BB:2, PB:5 and PB:10 compare favorably to the amounts of other mammalian proteins that have been produced in transgenic tobacco. Several studies where mammalian proteins had been expressed in transgenic tobacco were recently reviewed by Kusnadi et al. (1997), giving the following values $(\%$ in relation to total soluble protein): $0.02 \%$ of serum albumin, $0.0026 \%$ human erythropoietin and $0.1-0.5 \%$ calf chymosin. These amounts of expressed heterologous proteins are between 1.4 and 400-fold less than the amount of BB-CK produced, approximately $0.7-1.0 \%$, in this study (Table 2). The measured enzymatic activity of $\mathrm{CK}$ ranged from 0.1 to $0.3 \mathrm{U} / \mathrm{mg}$ of soluble protein in tobacco plants. This value is comparable to reported values of CK enzymatic activity in vertebrates (e.g., kidney) tissue that is relying on the CK energy circuit.

We have shown, to our knowledge for the first time that $\mathrm{Cr}$ can enter into plant cells. Moreover, we have conclusively demonstrated that $\mathrm{Cr}$ was converted into $\mathrm{PCr}$ in BB-CK-expressing plants. Although, we have a background value of $\mathrm{PCr}$ in the control line $\mathrm{Bi}: 1.3$ (Table 4) is probably due to the presence of a substance eluting in a similar position as $\mathrm{PCr}$ that oxidises $\mathrm{NADH}$ in the coupled enzymatic assay, rather than an intrinsic CK activity in plants. Although, one can not completely exclude this possibility. Such an activity would not be significant because it is 10 times lower in the control plant relative to $\mathrm{CK}$-expressing plants. With the CK activities detected the amount of $\mathrm{PCr}$ should be only dependent on the amount of available $\mathrm{Cr}$. Theoretically, the pools of $\mathrm{Cr}$ and $\mathrm{PCr}$ should be maintained by the $\mathrm{CK}$ reaction at an equilibrium ratio of approximately 1 to 2, respectively (Wallimann et al., 1998). However, an imbalance was observed between the pools of $\mathrm{Cr}$ and $\mathrm{PCr}$ (in a ratio 1 to 0.06) in BB-CK-expressing tobacco plants. This reflects compartimentation of $\mathrm{Cr}$ apart from the cytosol were BB-CK is expressed. Possibly, most of the $\mathrm{Cr}$ detected is trapped in the vascular tissue and only a small fraction is able to enter into the cells and can be converted to PCr. It is very unlikely that the detected $\mathrm{PCr}$ is due to a leakage of the enzyme in the vascular tissue. In such a situation, much more phosphocreatine would be synthesised from the extracellular pool and this is clearly not the case. If we consider a concentration of 80 nmols of ATP per $g$ of fresh weight (value reported for maize cells; Sowa et al., 1998), the concentrations of $\mathrm{PCr}$ obtained in tobacco plants (Tables 3 and 4) might be already sufficient to operate as a cellular energy buffering system in a similar way like in vertebrates.

The growth inhibition observed when plants were grown in $\mathrm{Cr}$ concentrations higher than $10 \mathrm{mM}$ could be caused by creatinine accumulation. $\mathrm{Cr}$ is continuously and non-enzymatically converted into Crn (Figure 1). We observed an accumulation of Crn in plants as well as in suspension cultures. In addition, when plants were grown in $10 \mathrm{mM}$ Crn growth was inhibited. Although, Crn has been reported to be present in some grain seeds and other vegetable matter $(\mathrm{Bu}-$ davari, 1989), neither $\mathrm{Cr}$ nor Crn was detected in tobacco plants grown without $\mathrm{Cr}$ supplementation in the media. The degradation of $\mathrm{Cr}$ into $\mathrm{Crn}$ can occur either in feeding media or in the plant cell or even in both. It is very unlikely that high amounts of $\mathrm{Cr}$ are converted to Crn in neutral cytosol. The rate of this conversion is rather slow at neutral $\mathrm{pH}$ but increases at acidic $\mathrm{pH}$ and such acidic $\mathrm{pH}$ values we have in the plant growth media (the starting $\mathrm{pH}$ of the medium is 5.8).

In conclusion, we have shown that the central enzyme in the phosphocreatine energy buffering system, $\mathrm{BB}-\mathrm{CK}$, can be functionally expressed in tobacco and is capable of converting $\mathrm{Cr}$ to $\mathrm{PCr}$ in plants. We have also demonstrated that $\mathrm{Cr}$ can enter the plant cell when supplied from an exogenous source. Obviously, exogenous supply of $\mathrm{Cr}$ is not the most convenient way to provide $\mathrm{Cr}$ to plants, but it is quite suitable for suspension cultures. More desirable approach would be construction of an integrated energy buffering 
circuit in plants, which can be obtained by introducing the enzymes that can extend the Arginine pathway to produce creatine (Kinney, 1998). Such an endogenous supply would overcome the problem of inefficient $\mathrm{Cr}$ entrance into the cytoplasm of plant cells. In addition, the growth of plants in soil would probably help to reduce the observed growth inhibition which may be caused by Crn accumulation. In the same way, growth of cell suspension cultures in a continuous mode of operation would probably overcome the $\mathrm{Crn}$ accumulation, which impairs growth. An alternative approach to overcome Crn toxicity would be to transform plants with the bacterial creatininase (creatinine amidohydrolase) that converts Crn into $\mathrm{Cr}$ (Wyss \& Kaddurah-Daouk, 2000). Such energy buffering systems in plants are desirable to overcome short-term energy deficits. Hence plants would have a broader range of tolerance to withstand and compete with a constantly changing climate and sudden environmental disasters.

\section{Acknowledgements}

We would like to thank Heidi Ernst for skillful DNA sequencing and Barbara Lennon for critical reading of this manuscript. This research was supported by the ETH.

\section{References}

Andersson CIJ, Holmberg N, Farrés J, Bailey JE, Bülow L and Kallio PT (2000) Error-prone PCR of Vitreoscilla hemoglobin $(\mathrm{VHb})$ to support the growth of microaerobic Escherichia coli. Biotechnol Bioeng 70: 446-455.

Bernt E, Bergemeyer HU and Mollering H (1974) Creatine. In: Bergemeyer HU (ed.) Methods in Enzymatic Analysis, Vol. 4 (pp. 1772-1776) Academic Press, New York.

Bradford MM (1976) A rapid and sensitive method for the quantification of microgram quantities of protein utilizing the principle of protein-dye binding. Anal Biochem 72: 248-254.

Brindle K, Braddock P and Fulton S (1990) ${ }^{31}$ P NMR measurements of the ADP concentration in yeast-cells genetically modified to express creatine-kinase. Biochemistry 29: 32953302.

Budavari S (1989) The Merck Index. An Encyclopedia of Chemicals, Drugs and Biologicals. MERCK \& CO., Rahway.

Celik I and Kara M (1997) The effects of plant growth regulators on activity of eight serum enzymes in vitro. J Environ Sci Heal 32: 1755-1761.

Eder M, Schlattner U, Becker A, Wallimann T, Kabsch W and FritzWolf K (1999) Crystal structure of brain-type creatine kinase at 1.41 Å resolution. Protein Sci 8: 2258-2269.

Edwards K, Johnstone C and Thompson C (1991) A simple and rapid method for the preparation of plant genomic DNA for PCR analysis. Nucl Acids Res 19: 1349.
Ellington WR and Hines AC (1991) Mitochondrial activities of phosphagen kinases are not widely distributed in the invertebrates. Biol Bull 180: 505-507.

Gallagher SR (1992) GUS Protocols. Using the GUS Gene as a Reporter of Gene Expression. Academic Press, San Diego.

Gallie DR (1998) Controlling gene expression in transgenics. Curr Opin Plant Biol 1: 166-172.

Hampp R, Hoffmann E, Schünherr K, Johann P and De Filippis L (1997) Fusion and metabolism of plant cells as affected by microgravity. Planta 203: S42-S53.

Kinney AJ (1998) Manipulating flux through plant metabolic pathways. Curr Opin Plant Biol 1: 173-178.

Kooter JM, Matzke MA and Meyer P (1999) Listening to the silent genes: transgene silencing, gene regulation and pathogen control. Trends Plant Sci 4: 340-347.

Koretsky AP, Brosnan MJ, Chen LH, Chen JD and Vandyke T (1990) NMR detection of creatine-kinase expressed in liver of transgenic mice - determination of free ADP levels. Proc Natl Acad Sci USA 87: 3112-3116.

Koretsky AP and Traxler BA (1989) The B-isozyme of creatinekinase is active as a fusion protein in Escherichia coli - In vivo detection by ${ }^{31} \mathrm{P}$ NMR. FEBS Lett 243: 8-12.

Kusnadi AR, Nikolov ZL and Howard JA (1997) Production of recombinant proteins in transgenic plants: practical considerations. Biotechnol Bioeng 56: 473-484.

Laemmli UK (1970) Cleavage of structural proteins during the assembly of the head bacteriophage T4. Nature 277: 680-685.

Linsmaier EM and Skoog F (1965) Organic growth factor requirements of tobacco tissue cultures. Physiol Plant 18: 100.

Miller K, Halow J and Koretsky AP (1993) Phosphocreatine protects transgenic mouse-liver expressing creatine-kinase from hypoxia and ischemia. Am J Physiol 265: C1544-C1551.

Murashige T and Skoog F (1962) A revised medium for rapid growth and bioassays with tobacco tissue cultures. Physiol Plant 15: 473-497.

Plaxton WC (1996) The organization and regulation of plant glycolysis. Annu Rev Plant Physiol Plant Mol Biol 47: 185-214.

Ricard B, Rivoal J, Spiteri A and Pradet A (1991) Anaerobic stress induces the transcription and translation of sucrose synthase in rice. Plant Physiol 95: 669-674.

Roenneberg T, Nakamura H and Hastings JW (1988) Creatine accelerates the circadian clock in a unicellular alga. Nature $\mathbf{3 3 4}$ : 432-434.

Roenneberg T and Taylor W (1994) Light-induced phase responses in Gonyaulax are drastically altered by creatine. J Biol Rhythms 9: $1-12$.

Rogers SG, Horsch RB and Fraley RT (1986) Gene-transfer in plants - production of transformed plants using Ti-plasmid vectors. Meth Enzymol 118: 627-640.

Sanger F, Nicken S and Coulson AR (1977) DNA sequencing with chain terminating inhibitors. Proc Natl Acad Sci USA 74: 54635467.

Saiki RK, Gelfand DH, Stoffel S, Scharf SJ, Higuchi R, Horn GT, Mullis KB and Erlich HA (1988) Primer-detected enzymatic amplification of DNA with a thermostable DNA polymerase. Science 239: 487-491.

Setter TL, Ellis M, Laureles EV, Ella ES, Senadhira D, Mishra SB, Sarkarung S and Datta S (1997) Physiology and genetics of submergence tolerance in rice. Ann Bot 79: 67-77.

Shen WJ and Forde BG (1989) Efficient transformation of Agrobacterium spp by high-voltage electroporation. Nucl Acids Res 17: 8385-8385.

Sowa AW, Duff SMG, Guy PA and Hill RD (1998) Altering hemoglobin levels changes energy status in maize 
cells under hypoxia. Proc Natl Acad Sci USA 95: 1031710321.

van Voorthuysen T, Regierer B, Springer F, Dijkema C, Vreugdenhil D and Kossmann J (2000) Introduction of polyphosphate as a novel phosphate pool in the chloroplast of transgenic potato plants modifies carbohydrate partitioning. J Biotechnol 77: $65-80$

Vartapetian BB and Jackson MB (1997) Plant adaptations to anaerobic stress. Ann Bot 79: 3-20.

Wallimann T, Dolder M, Schlattner U, Eder M, Hornemann T, O'Gorman E, Rück A and Brdiczka D (1998) Some new aspects of creatine kinase (CK): compartmentation, structure, function and regulation for cellular and mitochondrial bioenergetics and physiology. Biofactors 8: 229-234.

Wallimann T, Wyss M, Brdiczka D, Nicolay K and Eppenberger HM (1992) Intracellular compartmentation, structure and function of creatine-kinase isoenzymes in tissues with high and fluctuating energy demands - the phosphocreatine circuit for cellular-energy homeostasis. Biochem J 281: 21-40.

Watts CD (1971) Evolution of phosphagen kinases. In: Shoffeniels E (ed.), Biochemical Evolution and the Origin of Life. (pp. 150173) North-Holland, Amsterdam.

Watts DC (1973) Creatine kinase (adenosine-5'-triphosphatecreatine phosphotransferase). In: Boyer PD (ed.) The Enzymes. Vol. 8 (pp. 383-455) Academic Press, New York.

Wirz T, Brandle U, Soldati T, Hossle J and Perriard J (1990) A unique chicken B-creatine kinase gene gives rise to two Bcreatine kinase isoproteins with distinct $\mathrm{N}$ termini by alternative splicing. J Biol Chem 265: 11656-11666.

Wyss M and Kaddurah-Daouk R (2000) Creatine and creatinine metabolism. Phys Rev 80: 1107-1213.

Wyss M and Wallimann T (1994) I-4 Creatine metabolism and the consequences of creatine depletion in muscle. Mol Cell Biochem 133/134: 51-66. 